\title{
SOSIALISASI PENGOLAHAN BROWNIES KOPI PADA MASYARAKAT DESA TERUSAN BARU KABUPATEN EMPAT LAWANG
}

\author{
SOCIALIZATION OF COFFEE BROWNIES PROCESSING \\ IN TERUSAN BARU VILLAGE EMPAT LAWANG DISTRICT
}

\author{
${ }^{1)}$ Merynda Indriyani Syafutri, ${ }^{2)}$ Friska Syaiful, ${ }^{3)}$ Filli Pratama, ${ }^{4)}$ Anny Yanuriati, \\ ${ }^{5}$ Fanny Astari, ${ }^{6}$ Erlita Indah Astari, ${ }^{7)}$ Leonardo Yohanes H. Manurung \\ 1,2,3,4,5,5,7) Program Studi Teknologi Hasil Pertanian, Jurusan Teknologi Pertanian, \\ Fakultas Pertanian, Universitas Sriwijaya \\ Jalan Raya Palembang-Prabumulih KM 32 Indralaya, Ogan Ilir, Sumatera Selatan
}

*Email: misyafutri@gmail.com / merynda@fp.unsri.ac.id

\begin{abstract}
ABSTRAK
Terusan Baru adalah salah satu desa di Kecamatan Tebing Tinggi Kabupaten Empat Lawang Propinsi Sumatera Selatan. Sebagian besar penduduk Desa Terusan Baru bekerja sebagai petani kopi. Masyarakat desa ini mengolah biji kopi menjadi bubuk kopi, lalu bubuk kopi dijual. Masyarakat Desa Terusan Baru ada yang menjual dalam bentuk biji kopi kering. Bubuk kopi bisa diolah menjadi berbagai macam produk olahan pangan, seperti brownies. Pemanfaatan bubuk kopi dalam pembuatan brownies dimaksudkan untuk menambah varian rasa. Kegiatan pengabdian kepada masyarakat ini bertujuan untuk memberikan sosialisasi, penyuluhan, dan pelatihan mengenai teknologi pengolahan brownies berbahan baku bubuk kopi pada masyarakat Desa Terusan Baru. Jenis metode yang dilakukan adalah 1) uji hedonik terhadap rasa, warna, tekstur, dan aroma brownies kopi; 2) penyuluhan tentang teknologi pengolahan brownies kopi; serta 3) pelatihan (demonstrasi dan praktek) pembuatan brownies kopi. Tim pelaksana dalam kegiatan ini terdiri dari dosen, mahasiswa, dan alumni Program Studi Teknologi Hasil Pertanian Fakultas Pertanian Universitas Sriwijaya. Khalayak sasaran dalam kegiatan ini secara umum adalah masyarakat Desa Terusan Baru. Hasil kegiatan menunjukkan bahwa khalayak sasaran (masyarakat Desa Terusan Baru) sangat antusias dan berperan aktif dalam mengikuti kegiatan pengabdian. Para khalayak sasaran mengikuti semua kegiatan dengan baik mulai dari sosialisasi dan penyuluhan sampai pada kegiatan praktek. Hasil kegiatan juga menunjukkan bahwa bubuk kopi dapat diolah menjadi produk brownies dengan karakteristik sensoris yang disukai. Teknologi pengolahan brownies kopi sangat mudah dilakukan dan memiliki potensi untuk dikembangkan. Melalui kegiatan pengabdian kepada masyarakat ini, diharapkan masyarakat Desa Terusan Baru dapat mengaplikasikan materi yang telah disampaikan, serta dapat mengembangkan produk brownies kopi sebagai salah satu peluang usaha.
\end{abstract}

Kata kunci: Brownies; Kopi; Desa Terusan Baru

\section{ABSTRACT}

Terusan Baru is one of the villages in Tebing Tinggi District, Empat Lawang Regency, South Sumatra Province. Most of Terusan Baru Village residents work as coffee farmers. The villagers process coffee beans into coffee powder, and then it is sold. People of Terusan Baru Village also sell dried coffee beans. The coffee powder can be processed into various types of food products, such as brownies. The utilization of coffee powder in the manufacture of brownies is intended to add flavor variants. This activity aimed to provide socialization, counseling, and training on the processing technology of brownies made from coffee powder to the people of Terusan Baru Village. The type of method used was: 1) hedonic test of taste, color, texture, and aroma of coffee brownies; 2) counseling about coffee brownies processing technology; and 3) training (demonstration and practice) of making coffee brownies. The team in this activity consisted of lecturers, students, and alumni of the Agricultural Product Technology Study Program, Faculty of Agriculture, Universitas Sriwijaya. The target audience 
for this activity was the people of Terusan Baru Village. The results showed that the people of Terusan Baru Village were very enthusiastic and active in participating in these activities. They participated in all activities well, from socialization and counseling to practical activities. The results also showed that coffee powder could be processed into brownies products with preferred sensory characteristics. Coffee brownies processing technology was very easy to do, and had the potential to be developed. Through the activities, it was expected that the people of Terusan Baru Village could apply the material that had been delivered and can develop coffee brownies as a business opportunity.

Keywords: Brownies, Coffee, Terusan Baru village

Submitted: 13 Desember 2019 Revision : 31 Agustus 2020 Accepted : 19 September 2020

\section{PENDAHULUAN}

Tebing Tinggi merupakan salah satu kecamatan yang terletak di Kabupaten Empat Lawang Propinsi Sumatera Selatan. Tebing Tinggi juga merupakan ibu kota dari Kabupaten Empat Lawang, dimana kantor bupati dan kantor DPRD terletak di Kecamatan ini. Kecamatan Tebing Tinggi memiliki luas wilayah $362,93 \mathrm{Km}^{2}$ atau $16,08 \%$ dari total luas Kabupaten Empat Lawang (Badan Pusat Statistik Kabupaten Empat Lawang, 2016).

Salah satu desa yang terletak di Kecamatan Tebing Tinggi adalah Desa Terusan Baru. Desa Terusan Baru terletak sekitar $7 \mathrm{Km}$ dari ibu kota kecamatan yang sekaligus ibu kota kabupaten (Tebing Tinggi). Desa Terusan Baru memiliki area perkebunan yang cukup luas yaitu sekitar $30 \%$ dari luas desa. Salah satu tanaman perkebunan yang ditanam di Desa Terusan Baru yaitu tanaman kopi.

Bagian tanaman kopi yang biasa diolah oleh masyarakat di Desa Terusan Baru adalah biji kopi. Biji kopi diolah menjadi bubuk kopi melalui teknologi yang masih sederhana. Bubuk kopi yang dihasilkan kemudian dijual. Sebagian kecil masyarakat di Desa Terusan baru juga menjual dalam bentuk biji kopi kering. Bubuk kopi sebenarnya bisa ditambahkan dalam proses pengolahan berbagai macam produk olahan pangan, seperti kue semprong (Rihana, et al., 2020), kue Bhoi (Mustaqim et al., 2017), dan brownies (Sabara et al., 2017).
Brownies merupakan salah satu jenis kue yang mudah ditemui karena banyak dijual di berbagai toko kue, serta diminati dan digemari oleh banyak orang (Wahyuningtias et al., 2014). Menurut Widanti dan Mustofa (2015), saat ini brownies telah menjadi salah satu makanan populer di Indonesia. Brownies menjadi makanan yang banyak disukai berbagai kelompok usia dan status sosial.

Brownies merupakan kue yang memiliki tekstur yang lembut dan padat, berwarna coklat kehitaman, dan memiliki rasa khas coklat (Suhardjito, 2006). Wahyuningtias et al. (2014) menambahkan bahwa bahanbahan yang digunakan dalam pembuatan brownies adalah tepung terigu, telur, gula, mentega, dan coklat (coklat masak dan coklat bubuk). Mulyanto et al. (2020) menyatakan bahwa brownies dibuat dengan proses pemanggangan dan pengukusan.

Pemanfaatan bubuk kopi dalam pembuatan brownies dimaksudkan untuk menambah varian cita rasa brownies. Bubuk kopi dapat berfungsi sebagai flavoring sehingga bisa menjadi salah satu alternatif pada cita rasa produk brownies. Di pasaran, beberapa merek roti dan kue yang cukup terkenal telah mencoba memasarkan roti dan kue dengan rasa atau aroma kopi. Kopi memiliki aroma khas, sehingga konsumen juga banyak yang menyukai produk makanan dengan rasa atau aroma kopi tersebut. Zakaria et al. (2017) menambahkan bahwa budaya minum kopi yang sedang menjadi tren di masyarakat saat ini 
menjadi salah satu modal dalam pemasaran produk olahan kopi.

Melalui kegiatan pengabdian kepada masyarakat ini diharapkan dapat menambah pengetahuan dan keterampilan masyarakat Desa Terusan Baru Kabupaten Empat Lawang Propinsi Sumatera Selatan mengenai teknologi pengolahan brownies dari bubuk kopi. Selain itu, kegiatan ini juga dapat memberikan nilai tambah dan nilai ekonomis pada bubuk kopi. Kegiatan pengabdian kepada masyarakat ini juga diharapkan dapat mendukung program diversifikasi pangan berbasis produk hasil perkebunan lokal Sumatera Selatan (kopi).

\section{METODE}

Khalayak sasaran dalam kegiatan ini secara umum adalah masyarakat Desa Terusan Baru Kecamatan Tebing Tinggi Kabupaten Empat Lawang Propinsi Sumatera Selatan. Khalayak sasaran secara spesifik adalah petani kopi dan ibu-ibu PKK yang ada di Desa Terusan Baru. Tim pelaksana dalam kegiatan pengabdian kepada masyarakat ini terdiri dari 4 orang dosen, 1 orang mahasiswa, dan 2 orang alumni Program Studi Teknologi Hasil Pertanian Jurusan Teknologi Pertanian Fakultas Pertanian Universitas Sriwijaya.

Dalam kegiatan pengabdian kepada masyarakat ini digunakan beberapa metode dan dibagi menjadi 3 tahap kegiatan yaitu:

1. Uji hedonik (uji kesukaan) terhadap rasa, warna, tekstur, dan aroma brownies kopi dengan menggunakan 4 skala hedonik yaitu 1 (sangat tidak suka); 2 (tidak suka); 3 (suka); dan 4 (sangat suka). Kegiatan ini dilengkapi dengan kuisioner uji hedonik.

2. Penyuluhan dan pemberian materi tentang teknologi pengolahan, serta pengemasan untuk produk brownies kopi. Kegiatan ini dilengkapi dengan selebaran yang berisi materi kegiatan.

3. Pelatihan (melalui demonstrasi dan praktek) pembuatan brownies berbahan baku bubuk kopi secara langsung baik oleh pelaksana pengabdian maupun khalayak sasaran pengabdian.

\section{HASIL DAN PEMBAHASAN \\ Uji Hedonik Brownies Kopi}

Kegiatan pengabdian ini diawali dengan kegiatan uji sensoris produk brownies kopi yang dilaksanakan pada tanggal 11 September 2019 di Laboratorium Sensoris Jurusan Teknologi Pertanian Fakultas Pertanian Universitas Sriwijaya. Kegiatan ini bertujuan untuk menentukan konsentrasi bubuk kopi yang tepat dalam pembuatan brownies berdasarkan uji hedonik atau uji kesukaan.

Menurut Pratama (2013), uji hedonik merupakan uji yang digunakan untuk mengetahui tingkat kesukaan pada sampel uji. Uji hedonik dilakukan terhadap parameter rasa, warna, tekstur, dan aroma produk brownies kopi. Panelis berjumlah 50 orang, dan tergolong panelis semi terlatih.

Brownies yang diujikan pada uji hedonik ini memiliki konsentrasi penambahan bubuk kopi yang berbeda-beda, yaitu $10,15,20,25,30$, dan $35 \%$. Hasil uji hedonik menunjukkan bahwa panelis dapat menerima dan menyukai produk brownies dengan penambahan bubuk kopi untuk semua konsentrasi penambahan bubuk kopi. Panelis memberikan rerata skor penilaian (skor hedonik) berkisar antara 2,9 (suka) hingga 3,4 (suka) terhadap rasa, warna, tekstur, dan aroma brownies kopi.

Berdasarkan hasil uji hedonik, panelis yang mengkonsumsi kopi lebih dari dua kali sehari memberikan skor hedonik yang lebih tinggi pada brownies dengan konsentrasi bubuk kopi yang lebih tinggi (25-35\%), sedangkan panelis yang mengkonsumsi kopi kurang dari dua kali sehari memberikan skor hedonik yang lebih tinggi pada brownies dengan konsentrasi bubuk kopi lebih rendah (10-20\%). Oleh karena itu, konsentrasi kopi yang digunakan untuk kegiatan sosialisasi dan praktek pengolahan brownies kopi adalah konsentrasi 20\%. Konsentrasi tersebut digunakan karena penambahan 
bubuk kopi $20 \%$ merupakan konsentrasi yang disukai oleh semua golongan responden atau panelis.

\section{Penyuluhan Teknologi Pengolahan dan Pengemasan Brownies Kopi}

Kegiatan penyuluhan dan sosialisasi dilakukan di Desa Terusan Baru Kecamatan Tebing Tinggi Kabupaten Empat Lawang Propinsi Sumatera Selatan. Kegiatan dilakukan pada tanggal 19 Oktober 2019 di rumah Kepala Desa Terusan Baru. Kegiatan ini dihadiri oleh Kepala Desa Terusan Baru, para Kepala Dusun, Ketua PKK Desa Terusan Baru, serta masyarakat Desa Terusan Baru (petani kopi dan ibu-ibu PKK). Kegiatan ini juga dihadiri oleh anggota DPRD setempat.

Kegiatan ini bertujuan untuk memberikan penyuluhan dan sosialisasi kepada masyarakat Desa Terusan Baru, khususnya para petani kopi dan ibu-ibu PKK, bahwa bubuk kopi memiliki potensi untuk diolah menjadi produk makanan seperti brownies, teknologi pengolahan serta pengemasan brownies kopi. Tim pengabdian menginformasikan bahwa saat ini telah banyak produsen-produsen kue yang menambahkan bubuk kopi pada produk kue (seperti brownies, sus, dan lain-lain), dengan tujuan menambah varian cita rasa. Menurut beberapa hasil penelitian, sebagian besar panelis menyukai produk-produk kue yang ditambahkan kopi pada proses pengolahannya (Sabara et al., 2017; Mustaqim et al., 2017; Rihana et al., 2020). Kegiatan penyuluhan dan sosialisasi ini dapat dilihat pada Gambar 1.

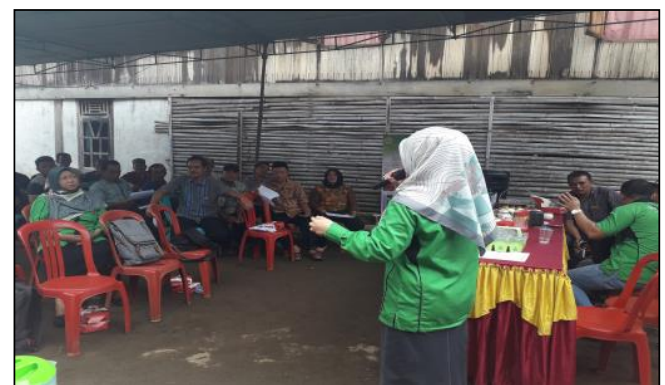

Gambar 1. Kegiatan penyuluhan dan sosialisasi pembuatan brownies kopi di Desa Terusan Baru

Tim pengabdian juga menjelaskan bahwa proses pengolahan brownies dengan penambahan bubuk kopi ini sangat mudah dilakukan. Hal tersebut dikarenakan alat-alat yang digunakan tergolong sederhana, bahanbahannya juga mudah didapat, proses pengolahan yang sederhana, serta waktu pengolahan yang tidak lama. Selain itu, masyarakat telah mengetahui cara pembuatan brownies secara umum.

Cara pembuatan brownies dengan penambahan bubuk kopi adalah sebagai berikut: telur ayam (4 butir) dan gula pasir $(200 \mathrm{~g})$ dicampur dan dikocok menggunakan mixer selama 15 menit (kecepatan 4) hingga mengembang. Kemudian ditambahkan tepung terigu (200 g) dan bubuk kopi (2 sdm), lalu diaduk hingga homogen. Adonan brownies yang telah homogen dimasukkan ke loyang. Loyang yang telah berisi adonan brownies dimasukkan ke dalam dandang yang telah dipanaskan sebelumnya dan diberi serbet pada bagian tutupnya. Pengukusan dilakukan selama 20 menit dengan api sedang. Brownies yang telah matang, didiamkan terlebih dahulu hingga dingin. Setelah itu diolesi dengan margarin pada permukaannya dan dilanjutkan dengan pemberian keju parut di atasnya. Brownies bubuk kopi siap disajikan (Sabara et al., 2017 yang dimodifikasi).

Tim pengabdian juga menyampaikan bahwa produk brownies ini bisa dijadikan sebagai salah satu peluang usaha. Oleh karena itu, dibutuhkan kemasan dengan tampilan yang menarik. Menurut Noviadji 
(2014), kemasan adalah wadah atau pembungkus bagi produk pangan yang memiliki peranan penting dalam upaya mempertahankan mutu dan keamanan pangan serta meningkatkan daya tarik produk. Pengemasan produk pangan ditujukan untuk melindungi bahan pangan segar maupun bahan pangan olahan dari penyebab kerusakan, baik fisik, kimia, maupun mekanis.

Pada kegiatan penyuluhan dan sosialisasi ini, tim pengabdian menjelaskan mengenai pentingnya kemasan untuk menambah daya tarik dari produk brownies yang dibuat. Yamin et al. (2018) menyatakan bahwa nilai tambah sebuah produk menjadi berkali lipat dengan menambahkan kemasan yang menarik.

Jenis kemasan yang diperkenalkan pada kegiatan ini adalah kemasan plastik mika. Noviadji (2014) menyatakan bahwa kemasan buatan manusia seperti kertas, plastik, kaleng, dan styrofoam menciptakan kesan modern, praktis, dan bersih.

Tim pengabdian juga memberikan informasi tentang label pada kemasan. Menurut PP No. 69 tahun 1999 pasal 1 ayat 3 , label adalah keterangan mengenai pangan yang berbentuk gambar, tulisan, kombinasi keduanya atau bentuk lain yang disertakan pada pangan, dimasukkan ke dalam, ditempelkan pada, atau merupakan bagian kemasan pangan (Supraptiningsih, 2006). Pada label di kemasan produk brownies kopi ini dicantumkan nama produk, komposisi bahan, nama produsen, dan informasi lainnya terkait dengan produk brownies kopi. Tim pengabdian memperkenalkan produk brownies kopi dengan nama "Bro-Coffee".

Tim pengabdian juga memberikan bantuan alat-alat yang digunakan untuk pengolahan brownies dengan penambahan bubuk kopi (Gambar 2). Alat-alat tersebut diserahkan secara simbolis oleh tim pengabdian kepada Ibu Kepala Dusun II Desa Terusan Baru. Alat-alat ini dijadikan sebagai inventaris ibu-ibu PKK Desa Terusan Baru dan diharapkan dapat digunakan untuk kegiatan PKK, terutama dalam mengolah brownies kopi.

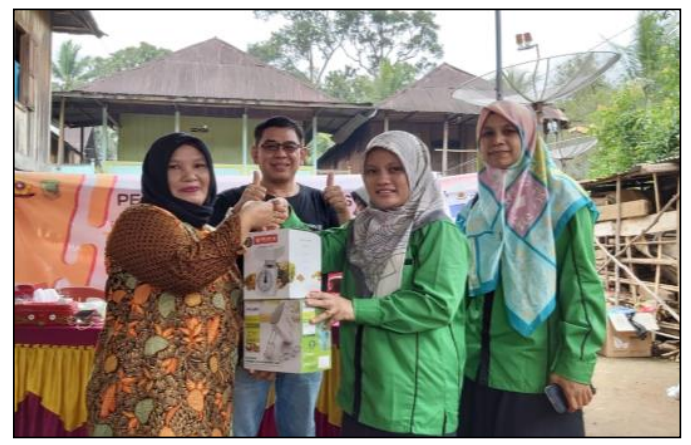

Gambar 2. Penyerahan bantuan alat secara simbolis oleh tim pengabdian kepada Kadus

II Desa Terusan Baru

Para khalayak sasaran (peserta pengabdian) antusias dalam mengikuti kegiatan sosialisasi dan penyuluhan ini. Hal ini dibuktikan dengan kehadiran sasaran yang tepat waktu, jumlah masyarakat yang hadir (hampir 40 orang), serta pertanyaanpertanyaan yang diajukan ketika tahap diskusi berlangsung. Dengan adanya kegiatan sosialisasi dan penyuluhan ini, maka pengetahuan dan pemahaman masyarakat Desa Terusan Baru, khususnya para petani kopi dan ibu-ibu PKK, mengenai potensi bubuk kopi, teknologi pengolahan, pengemasan, serta pelabelan brownies kopi dapat bertambah. Kepala desa beserta masyarakat Desa Terusan Baru berharap bahwa kegiatan seperti ini dapat terus dilaksanakan untuk membuka wawasan dan memotivasi masyarakat Desa Terusan Baru.

\section{Praktek Teknologi Pengolahan dan} Pengemasan Produk Brownies Kopi

Kegiatan praktek teknologi pengolahan dan pengemasan produk brownies dengan penambahan bubuk kopi juga dilaksanakan pada tanggal 19 Oktober 2019 di rumah Kepala Desa Terusan Baru Kecamatan Tebing Tinggi Kabupaten Empat Lawang. Kegiatan ini dilakukan setelah kegiatan sosialisasi dan penyuluhan selesai dilakukan. Kegiatan praktek ini bertujuan untuk memberikan contoh langsung kepada peserta 
pengabdian tentang pembuatan dan pengemasan produk brownies kopi.

Pada kegiatan praktek ini, tim pengabdian melibatkan peserta pengabdian (ibu-ibu PKK Desa Terusan Baru) untuk membuat produk brownies kopi, mulai dari persiapan alat dan bahan sampai pada praktek pengemasan produk (Gambar 3). Tim pengabdian juga memberikan penjelasan terkait praktek pembuatan dan pengemasan produk, sehingga diharapkan peserta pengabdian dapat lebih memahami materi yang disampaikan.

Berdasarkan indikator keberhasilan, kegiatan praktek ini dapat dikatakan berhasil. Hal ini dikarenakan para peserta pengabdian sangat antusias mengikuti kegiatan praktek, bahkan masyarakat ikut terlibat dalam kegiatan praktek pembuatan brownies dengan penambahan bubuk kopi. Masyarakat terlihat sangat termotivasi untuk mengembangkan produk brownies bubuk kopi. Hal ini disampaikan oleh Kepala Dusun II Desa Terusan Baru. Materi tentang pengolahan brownies bubuk kopi ini akan diteruskan ke ibu-ibu PKK lainnya. Selain itu, ada beberapa anggota PKK yang ingin menjual produk brownies bubuk kopi ini sebagai makanan jajanan di sekolah-sekolah.

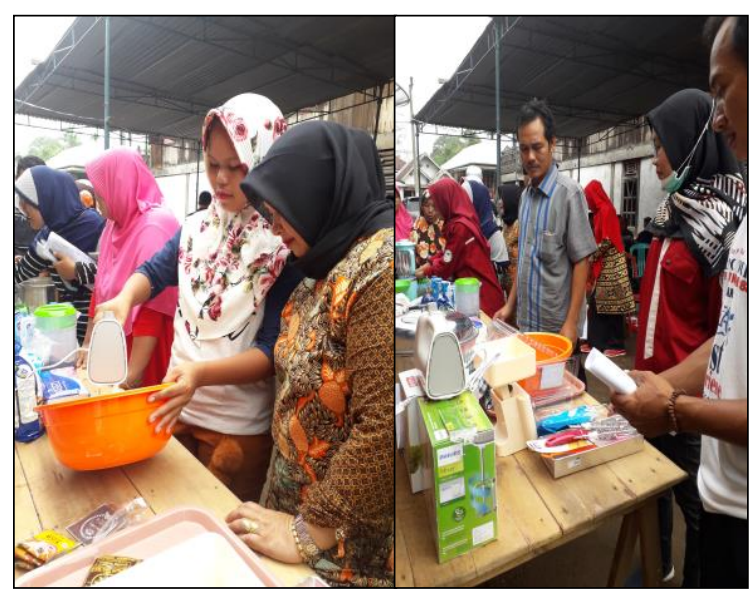

Gambar 3. Kegiatan praktek pembuatan brownies kopi

Motivasi peserta pengabdian semakin meningkat setelah produk brownies kopi berhasil dibuat dan diuji coba oleh masyarakat. Produk brownies bubuk kopi yang dihasilkan memiliki karakteristik sensoris yang baik, mulai dari penampakan secara umum, warna, aroma, rasa dan tekstur. Tampilan produk semakin menarik setelah dikemas dengan kemasan yang telah disiapkan (Gambar 4).

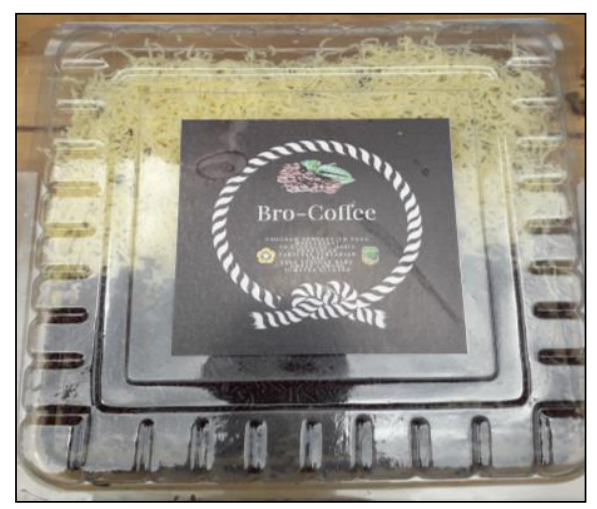

Gambar 4. Brownies kopi hasil kegiatan praktek yang telah dikemas

\section{SIMPULAN}

Kesimpulan yang dapat diperoleh dari kegiatan pengabdian kepada masyarakat ini adalah bubuk kopi berpotensi untuk diolah menjadi produk brownies. Produk brownies dengan penambahan bubuk kopi dapat diterima secara sensoris. Selain itu, masyarakat Desa Terusan Baru mendapatkan pengetahuan dan pemahaman tentang pengolahan dan pengemasan produk brownies dengan penambahan bubuk kopi.

\section{DAFTAR PUSTAKA}

Badan Pusat Statistik Kabupaten Empat Lawang. (2016). Kabupaten Empat Lawang dalam Angka. BPS Kabupaten Empat Lawang.

Mulyanto, B.P., Wulandari, Y.W. \& Mustofa, A. (2020). Karakteristik Brownies Kukus Tepung Jewawut (Setarica italica) dan Tepung Maizena dengan Pengaruh Lama Proses Pengukusan. Jurnal Ilmiah Teknologi 
dan Industri Pangan UNISRI. 5(1), 111 .

http://dx.doi.org/10.33061/jitipari.v5i1. $\underline{3131}$

Mustaqim, Erfiza, N.M. \& Widayat, H.P. (2017). Pembuatan Kue Bhoi dengan Substitusi Tepung Mocaf (Modified Cassava Flour) dan Penambahan Bubuk Kopi. Jurnal Ilmiah Mahasiswa Pertanian Unsyiah. 2(4), 471 - 477. https://doi.org/10.17969/jimfp.v2i4.132 8

Noviadji, B.R. (2014). Desain Kemasan Tradisional dalam Konteks Kekinian. ARTIKA : Jurnal Fakultas Desain. 1(1), 10 21. https://doi.org/10.34148/artika.v1i1.24

Pratama, F. (2013). Evaluasi Sensoris. Unsri Press: Palembang.

Ridwansyah. (2003). Pengolahan Kopi. Jurusan Teknologi Pertanian Fakultas Pertanian Universitas Sumatera Utara. Sumatera Utara.

Rihana, Prisilia, E. \& Efrina, E. (2020). Uji Daya Terima Terhadap Modifikasi Kue Semprong dengan Penambahan Ekstrak Kopi Instan. Prosiding Seminar Nasional Penelitian dan Pengabdian Masyarakat Universitas Islam Majapahit, 16 - 20.

Sabara, R.A., Tamrin, \& Asyik, N. (2017). Pengaruh Penambahan Bubuk Kopi Terhadap Karakteristik Organoleptik Produk Brownies. Jurnal Sains dan Teknologi Pangan. 2(1), 370 - 381. http://dx.doi.org/10.33772/jstp.v2i1.212 8

Suhardjito, Y.B. (2006). Pastry and Perhotelan. Andi. Yogyakarta.

Supraptiningsih, U. (2006). Pentingnya Pencantuman Label Pangan pada Produk-produk Pangan/Camilan untuk Perlindungan Konsumen. Al-Ihkam : Jurnal Hukum dan Pranata Sosial. 1(2),
199 -211. http://dx.doi.org/10.19105/allhkam.v1i2.2563

Wahyuningtias, D., Putranto, T.S. \& Kusdiana, R.N. (2014). Uji Kesukaan Hasil Jadi Kue Brownies Menggunakan Tepung Terigu dan Tepung Gandum Utuh. BINUS Business Review. 5(1), 57-65. https://doi.org/10.21512/bbr.v5i1.1196

Widanti, Y.A. \& Mustofa, A. (2015). Karakteristik Organoleptik Brownies dengan Campuran Tepung MOCAF dan Tepung Ketan Hitam dengan Variasi Lama Pemanggangan. Joglo. 27(2), $272-280$.

Yamin, M.M., Abidin, E.E. \& Sulaeman. (2018). Sosialisasi Pengemasan Kue Tradisional Di Desa Sepabatu, Kec. Tinambung, Kab. Polewali Mandar. RESONA : Jurnal Ilmiah Pengabdian Masyarakat. 2(1), $31 \quad-\quad 41$. http://dx.doi.org/10.35906/jipm01.v2i1. 309

Zakaria, A., Aditiawati, P. \& Rosmiati, M. (2017). Strategi Pengembangan Usaha Tani Kopi Arabika (Kasus pada Petani Kopi di Desa Suntenjaya Kecamatan Lembang Kabupaten Bandung Barat, Provinsi Jawa Barat. Jurnal Sosioteknologi. 16(3), 325 - 339. http://dx.doi.org/10.5614\%2Fsostek.itbj .2017.16.3.7 